Chirurgia (2017) 112: 482-485

No. 4, July - August

Copyright $\odot$ Celsius

http://dx.doi.org/10.21614/chirurgia.112.4.482

\title{
Breast Recurrent Hydatid Cyst Disease
}

\author{
Ayetullah Temiz', Yavuz Albayrak', Sevilay Özmen Akalp² Ahmet Yalçın $^{3}$, Ayșe Albayrak ${ }^{4}$ \\ 'Department of General Surgery, Erzurum Region Education and Research Hospital, Erzurum, Turkey \\ ${ }^{2}$ Department of Pathology, Erzurum Region Education and Research Hospital, Erzurum, Turkey \\ ${ }^{3}$ Department of Radiology, Erzurum Region Education and Research Hospital, Erzurum, Turkey \\ ${ }^{4}$ Department of Infectious Diseases and Clinical Microbiology, Ataturk University, Faculty of Medicine, Erzurum, Turkey
}

Corresponding author:

Ayetullah Temiz, MD

Adnan menderes Mah. Hilal Sok.

Bulutlar Deren Sitesi №:31/25100

Palandöken- Erzurum, Turkey

E-mail: temiz-49@hotmail.com

\section{Rezumat}

Hidatidoză mamară recurentă: prezentare de caz

Introducere: Chistul hidatic este o zoonoză întâlnită în zonele endemice. Aceasta reprezintă o reală problemă în țara noastră, cu precădere în zona de est şi sud-est, reprezentată de Regiunea Anatolia. Invadarea de țesut mamar izolat este foarte rară în boala hidatică. Din câte cunoaştem, hidatidoza izolată mamară recurentă nu a fost raportată până acum în literatură.

Prezentare de caz: Scopul nostru este de a prezenta cazul unei paciente diagnosticată cu boală hidatică izolată mamară recurentă ipsilateral, prezentând o intervenție chirurgicală pentru hidatidoză la nivelul glandei mamare drepte în urmă cu 9 ani.

Concluzie: Boala hidatică trebuie luată în considerare în diagnosticul diferențial al maselor mamare cu aspect chistic, în special în zonele endemice. Dacă pacienta a fost supusă în antecedente unei intervenții chirurgicale pentru boală hidatică mamară, hidatidoza mamară recurentă trebuie luată în considerare la momentul diagnosticului diferențial.

Cuvinte cheie: chist hidatic, sân, recurență

\section{Abstract}

Introduction: Hydatid cyst is a zoonotic disease seen in endemic areas. It is an important health problem in our country and especially in our Eastern and South-eastern Anatolia Region. Involvement of isolated breast tissue is very rare in hydatid cyst 
disease. As far as we know, isolated recurrent breast cyst hydatidosis has not been found in the literature.

Case report: We aimed to present the case of a patient who was diagnosed with recurrent isolated cyst hydatid in the same breast, operated on because of hydatid cyst in the right breast 9 years ago. Conclusion: A hydatid cyst should be considered, particularly in endemic regions, in the differential diagnosis of cystic masses of the breast. If the patient has previously undergone surgery for breast cyst hydatid disease, recurrent cyst hydatid disease should be considered at the differential diagnosis.

Key word: hydatid cyst, breast, recurrent

\section{Introduction}

Hydatid cyst or echinococcosis is a zoonotic disease seen in sheep-raising areas in the world. It is to us an important health problem in our country and especially in our region, East and South-eastern Anatolia Region (1,2). Although the most common site is the liver, there are hydatid cyst cases developed in almost every part of the body in the literature. Liver and lung hydatid cysts account for about $90 \%$ of all cases (3). Involvement of isolated breast tissue is very rare in hydatid cyst disease. As far as we know, isolated recurrent breast cyst hydatidosis has not been found in the literature. We aimed to present the case of a patient who was also operatedin our clinic with recurrent isolated cyst hydatid in the same breast, and operated because of isolated hydatid cyst in the right breast 9 years ago.

\section{Case Report}

A 36-year-old female patient presented with a complaint of right breast mass. From the personal history of the patient, who is married and has two children, it was understood that she addressed our clinic and was operated for the same complaint and in the same breast 9 years ago. Previous records show that she was operated due to a cystic mass in the right breast and the pathology result was reported as hydatid cyst (Fig. 1). A tender soft, mobile and well-defined mass of approximately $3 \times 4$ $\mathrm{cm}$ in size was palpated in the right breast on physical examination. The examination of the bilateral axillary region of the left breast and other systems was normal. Breast ultrasound exam showed complicated multilocular cystic type lesion (hydatid cyst?), of solid component, $37 \times 21 \mathrm{~mm}$ size, at a $5 \mathrm{~cm}$ distance from the nipple, in the first quadrant of the right breast. Breast MRI showed a 36x42 mm sized cystic lesion, with peripheral and septal contrasting, with smooth lobulated contour and septations, in the right breast upper-inner quadrant (Fig. 2). Pathological finds were not detected in any other part of the body on the thoracoabdominal tomography (Fig. 3). Preoperative indirect hemaglutination test was negative. Surgical excision under general anaesthesia was performed, following medical treatment for two weeks with Albendazole $10 \mathrm{mg} / \mathrm{kg} /$ day in two daily doses, Albendazole $10 \mathrm{mg} / \mathrm{kg}$ / day in two daily doses was continued for three months After surgery, recurrence was not detected at the 3-month follow-up examination.

\section{Discussion}

Recurrent hydatid cyst disease is the occurrence of new live cysts after cyst treatment. If recurrent disease is present in the area where the primary disease has been treated, it is called local recurrence. If the disease recurs somewhere far from where it was initially treated, it is called disseminated disease. There are different causes and patterns of emergence for both types of recurrence (4). Our case is considered local recurrence because the disease recurred in the upper inner quadrant of the right breast, while the disease present previously was located in the 


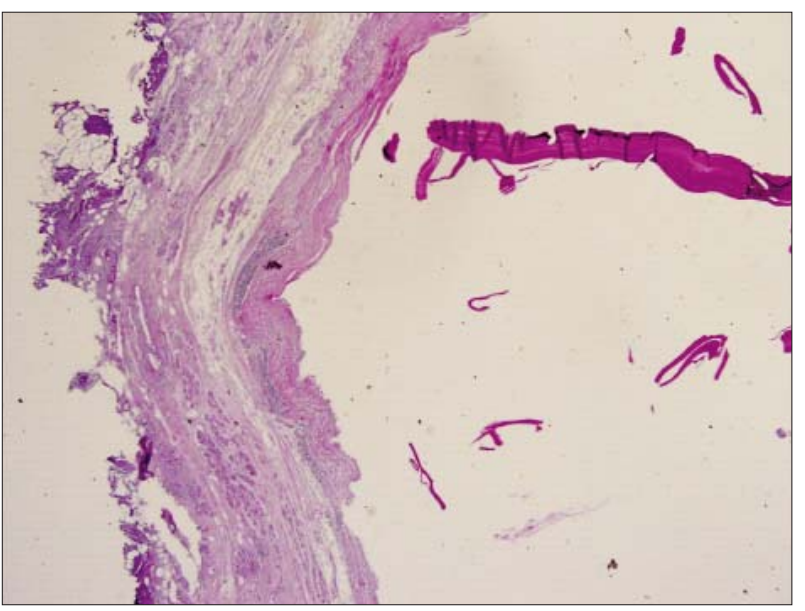

Figure 1. At the histopathological examination of the former case, a membrane showing a lamellar concentric sequence was observed in the vicinity of the breast tissue including fibrosis-adenosis and mastitis findings. Histochemically, this membrane of hydatid cyst shows staining with PAS (hematoxylin-eosin, original magnification $\times 100$ ).

upper outer quadrant of the right breast.

The recurrence frequency of hydatid cyst disease is presented at different rates in various series. The recurrence rate of the disease within the 5-year follow-up period has been reported between $0.9-11.3 \%$ in the literature $(5,6)$. However, there is no available data related to recurrent cyst hydatid disease of the breast in the literature. Reasons for recurrence of hydatid cyst disease include: spreading to the area when the cyst contents are evacuated, improper use of

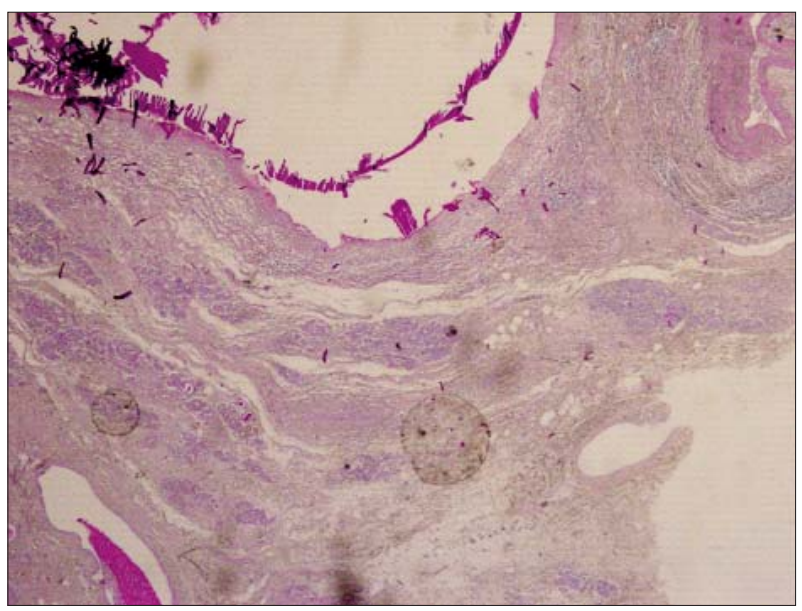

Figure 2. At the histopathological examination of the recurrent case, the membrane structure showing a lamellar concentric sequence with PAS positivity was observed adjacent to chronic inflammatory granulation tissue (hematoxylin-eosin, original magnification x 100)

scolicidal agents, cysts whose diagnosis is skipped before and after surgery, the living elements of the cysts cannot be completely removed during the first operation and the pericystic pocket cannot be reached when conservative treatment is applied $(5,7)$.

The breast is an extremely rare site for hydatid cysts and the ratio in all cyst hydatidoses is reported to be about $0.27 \%$ (8). The diagnosis of the disease is made by history, physical examination, radiology and serologi-

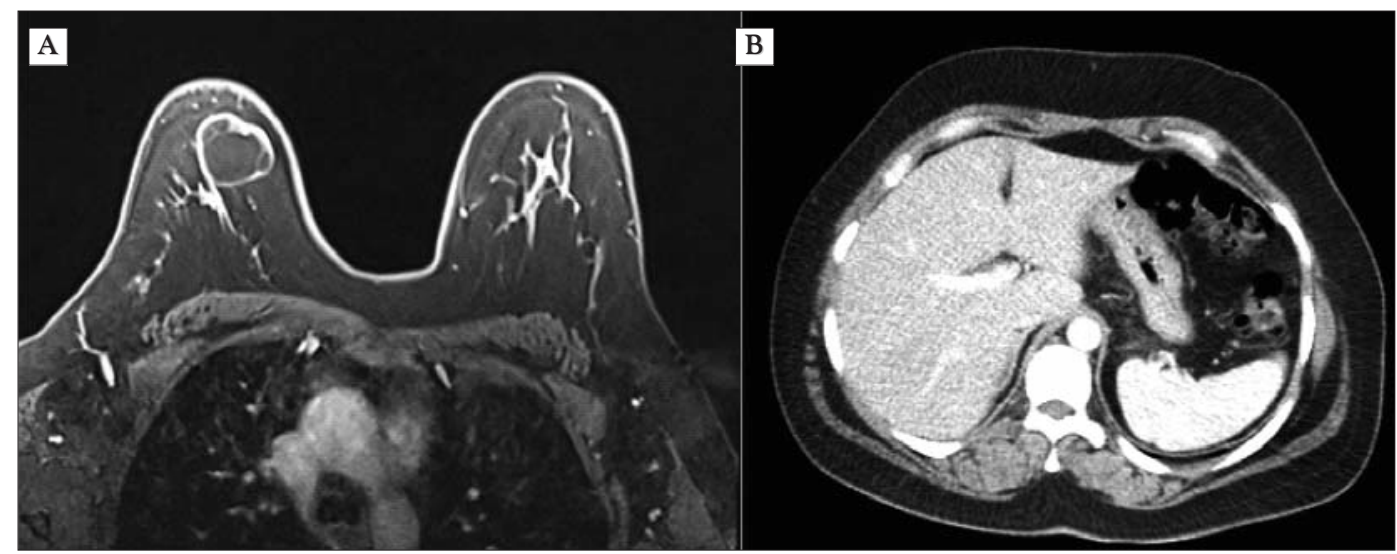

Figure 3. Axial T1 weighted contrast enhanced image of breasts (A) A cystic lesion with peripheral contrast enhancement was seen in the right breast. Axial contrast enhanced CT image acquired at the level of the liver. (B) There are no lesions detected within the liver 
cal tests. The final diagnosis is set based on the pathology exam. It generally affects women between 30 and 50 years of age. On examination, a smoothly limited, mobile mass is palpable. At mammography, it is seen as a homogenous, with a smooth contour, round, nonspecific lesion. It might mimic fibroadenoma, phyllodes tumours, chronic abscesses and other cystic lesions of the breast $(9,10)$. Mammography may show circumscribed mass lesion with ring-shaped structures inside the mass (10). Ultrasonography shows lesions that are multiple cysts and include solid areas smoothly restricted, with lobulated contours in the breast $(9,10)$. MR imaging shows a welldefined cystic lesion showing capsular contrast enhancement. The indirect hemaglutination test supports diagnosis. Preoperatively fine needle aspiration biopsy can establish the diagnosis by the observation of stratified membranes or hooks (11). We did not need fine needle aspiration biopsy because our patient presented with recurrence and radiology examination also supported the diagnosis. A definitive diagnosis was made by pathological examination. Treatment of breast primary hydatid cyst disease is surgical cystectomy (11). In addition, it has been reported that pre- and post-operative treatment with mebendazole reduces the risk of recurrence (12).

\section{Conclusion}

As a result, it is difficult to differentiate cyst hydatid lesions from other masses of the breast. A hydatid cyst should be considered, particularly in endemic regions, in the differential diagnosis of cystic masses of the breast. If the patient has previously undergone surgery for breast cyst hydatid disease, recurrent cyst hydatid disease should be considered at the differential diagnosis.

\section{Conflicts of Interest and Source of Funding}

This study has no research funding or organisations.

\section{References}

1. Eckert J, Deplazes P. Biological, epidemiological, and clinical aspects of echinococcosis, a zoonosis of increasing concern. Clin Microbiol Rev. 2004;17(1):107-35.

2. Torgerson PR, Williams DH, Abo-Shehada MN. Modelling the prevalence of Echinococcus and Taenia species in small ruminants of different ages in northern Jordan. Vet Parasitol. 1998;79(1):35-51.

3. McManus DP1, Zhang W, Li J, Bartley PB. Echinococcosis. Lancet. 2003;362(9392):1295-304.

4. Sahin A, Çilekar M, Karakaș BR. Intraabdominal kist hidatigin komplikasyonları. Türkiye Klinikleri J Surg Med sci2006,2(9):17-27.

5. Secchi MA, Pettinari R, Mercapide C, Bracco R, Castilla C, Cassone $E$, et al. Surgical management of liver hydatidosis: a multicentre series of 1412 patients. Liver Int. 2010;30(1):85-93. doi: 10.1111/ j.1478-3231.2009.02116.x. Epub 2009 Sep 11.

6. Amir-Jahed AK, Fardin R, Farzad A, Bakshandeh K. Clinical echinococcosis. Ann Surg. 1975;182(5):541-6.

7. Gottstein B. Molecular and immunological diagnosis of echinococcosis. Clin Microbiol Rev. 1992;5(3):248-61.

8. Taori KB, Mahajan SM, Hirawe SR, Mundhada RG. Hydatid disease of the breast. Indian J Radiol Imag. 2004;14:57-60.

9. Vega A, Ortega E, Cavada A, Garijo F. Hydatid cyst of the breast: mammographic findings. AJR Am J Roentgenol. 1994;162(4):825-6.

10. Yaghan RJ. Hydatid disease of the breast: a case report and literature review. Am J Trop Med Hyg. 1999;61(5):714-5.

11. Sağin HB, Kiroğlu $Y$, Aksoy $F$. Hydatid cyst of the breast diagnosed by fine needle aspiration biopsy. A case report. Acta Cytol. 1994; 38(6):965-7.

12. Uncu H, Erekul S. Hydatid cyst of the breast. Acta Chir Belg. 2007; 107(5):570-1. 